\title{
Training Management Based on Digital Marketing in Increasing Enterprise Motivation for Micro, Small and Medium Enterprises in Cimahi City
}

\author{
(Descriptive Study on Organizing the Micro, Small and Medium Enterprises Training \\ Program in Cimahi City)
}

\author{
Ade Sadikin, Oong Komar*, Cucu Sukmana \\ Community Education Department \\ Universitas Pendidikan Indonesia \\ Bandung, Indonesia \\ *prof.oongkomar@upi.edu
}

\begin{abstract}
During the COVID-19 pandemic, the nation's economy is suffering due to limited activities, restraining people from having any physical contact during the process of buying and selling. The pandemic has made it difficult for smaller businesses not only to develop, but also to maintain their business. In order to survive the pandemic, many UMKM (abbreviation for smaller businesses in Bahasa) in Cimahi are deemed necessary to get a digital marketing training. This study aims to describe the management process of a digital marketing training program in order to improve entrepreneurial motivation for smaller business owners in Cimahi. This research includes a study on smaller business players who take the digital-based training. To reveal these data and information, the researchers are describing in detail using descriptive study method with a qualitative approach to reveal the depth of data and information based on the problem discussed in this research: how to manage digital marketing training programs to improve entrepreneurial motivation for smaller business owners in Cimahi? In a digital marketing training system, the cycle is divided into 3 stages: program planning, program implementation, and program evaluation. The implementation process must begin with a needs analysis, then use the data compiled from the analysis to design a digital marketing training program, then proceed to develop materials for the training before conducting the program and program's evaluation at the end.
\end{abstract}

Keywords-training programs, digital marketing, entrepreneurial motivation

\section{INTRODUCTION}

The development of national education in Indonesia is still facing mainly three big and very complex challenges. The first challenge is the impact of the economic crisis, as well as the current state of the education field that is required to maintain a steady development of the society. The second challenge, is to expect a faster pace of developments globally, hence education is required to produce high quality human resources in order to compete in the global job market. Furthermore, the third challenge, is in line with the local regulations of the regional government necessary to make changes and adjustments to the national education system in order to realize a more democratic education system while also paying attention to the diversity of needs / conditions of the region and students to seek for significant improvement as well as including a larger scale of the society's participation. Apart from that, the national education also faces a number of problems which are: (1) education inequality; (2) low quality education and lack of relevance; and (3) furthermore, lack of educational management, in addition to this, an independent technology realization has not been realized amongst academics. According to Soewardi [1], smaller business players have relatively limited choices, especially in relation to any program held by other institutions can cause loss of independence as they become more dependent to outside forces. Margono [2] implied that this dependence is not only in terms of obtaining information, but also in making decisions. This response is in line with the statement of Abbas et al. [3] which explains that farmers are still very eager to carry out a program conducted by the government in order to maintain stability. Saragih [4] also explained that the despite the ability of farmers in the field of agriculture has certainly increased business productivity, the income earned is rather small.

Basically, this country owns an abundant amount of lands, fitting for the community to turn this geographic condition into business to get a high selling price in the global market. But, what is the reality of what happened in the field according to the Central Bureau of Statistics? To what extent is the level of the nation's agricultural corps can win over the global market competition [5]?

A similar research also states that digital marketing training is a form of marketing that uses tools to make it easier as well 
as a strategy to compete with other companies or businesses, through several websites that can be used as a place for entrepreneurs to market their products such as blogs, e-mails, online ads, as well as Instagram and YouTube [6]. Another view related to digital marketing implies that is a perspective on social media as a promotional material for an item or service to seek effective and efficient buying community that can help increase sales significantly.

Empowerment or a state of independence which is a manifestation of the ability of individuals is the outcome of the efforts made by people to meet their daily needs [7] which explains that it is expected for farmers to grow and foster independence, in order to increase their strengths individually to fulfil their needs.

Problems regarding entrepreneurship in Indonesia, especially in Cimahi, is rooted from the lack of attention for small and medium industries (IKM) which really need a directed program that will help the community improve its quality and strengthen the national economy, as well as to utilize an effective strategy to distribute both goods or services. The presence of small and medium industries in the community will have a very significant impact, especially for those who are currently facing the monetary crisis. These small-medium industries play a big role in relation to the existence of economic and social problems in the country. The high levels of poverty, increasing numbers of unemployment and payment inequality, as well as imbalanced human development has raised many social controversies within the community. In this case, it is very necessary to conduct a program that can help the community to navigate this competitive era of global trades.

Furthermore, the N Ach (Nedd for Achievement) is based on a personal guide which can be analysed individually. $\mathrm{N}$ Ach is an important sign of encouragement to entrepreneurship as motivation arises due to the desire to achieve something. Then, each individual may realize the meaning of his own achievements, believing that these achievements should be able to encourage the realization of a better living. Motivating entrepreneurs requires a highly driven spirit to be successful, desires to learn by seeing the success of other people's achievements, and a strong will to solve problems by using entrepreneurship principles. McClelland [8] stated that the main psychology behind motivating entrepreneurs lies within their need for achievement, previously known as N Ach which can define various impulses that motivates a person to develop a behaviour towards achieving the goal of the program.

\section{RESEARCH METHODS}

This approach uses a qualitative study by prioritizing the overall view, which emphasizes the views of the subjects without coercion from the researchers. Data collection was carried out by interview and participant observation [9]. Drafted using a random sampling method, the informants of this study were 1 manager, 1 instructor, and 1 participant of the digital marketing training. The focus of this research were the managers, because this study aims to manage the implementation of training programs. Data analysis was carried out in several stages: writing, editing, classifying data, reducing, and providing data interpretations.

\section{FINDINGS AND DISCUSSION}

\section{A. How Can We Manage the Implementation of Digital Marketing Training Programs to Increase Entrepreneurial Motivation?}

Any institution requires management because humans as individuals have limited abilities. Management is a set of skills to carry out training programs, with other people or through other people in order to achieve goals. Management is also performed through a series of activities carried out with groups to achieve the set goals within an organization [10]. Management includes several functions, which are: planning, formulating organizational system, mobilizing and monitoring training programs, and conducting assessments. Likewise, a good training program requires a good management so that the training is carried out beneficially for the participants, the organization, and the community [11]. A good management is needed so that training can run accordingly to the objectives that need to be achieved and is beneficial to the individual itself, the institution / organization, and the community [10] Researchers reveal the steps for managing the implementation of digital marketing training as follows

- At the beginning, participants who wanted to take part in this digital marketing training were recruited. The participants or the community who take part in this program are the main figures especially in determining the success of implementing the digital marketing training program. At this stage, the manager or organizer can determine the predetermined requirements that need to be met by participants, especially those who have a characteristic that can participate in the program prior to implementation.

- Three sources that can be used as a basis for identifying learning needs are individuals who are provided with digital marketing training services, organizations and or institutions as sponsors, and the community as a whole. As for the characteristics that can be used as a reference for the implementation of this program are both from internal and external perspectives. The internal factors are observed through participants' needs, interests, and experiences, while the external factors are related to family backgrounds and social status.

- In relations to learning needs, we need to identify learning resources and possible obstacles. Basically, the identification of learning needs is an activity that looks for data related to the participants' needs that are expected to be accommodated in the program. If you want to determine your learning needs, you can use a variety of approaches. There are 3 sources that can be used as initial parameters in identifying learning needs, namely from a person who is experienced in training 
program services, as well as organizations, and related institutions that work together to become sponsors of those programs, as well as the community in general.

- To determine and create a digital marketing training goal formula, the digital marketing training objectives that have been predetermined will carry out training from the beginning to the end of the training program. Determining training objectives can be done very carefully. In general, the aim of this training is the outcome or results that must be achieved by the end of the training program. Therefore, training objectives should be specific, clear, and concrete.

- The next step is to develop a tool for conducting the initial evaluation and final evaluation. The evaluation stage aims to identify the entry behavioural levels of the digital marketing training participants. Then, to design training materials and determine a learning method that is appropriate for use and to place training participants proportionally. This final stage evaluation is aims to measure how well the materials are received by the digital marketing training participants.

- Organizing the order of the digital marketing training activities. During this stage, the implementation of a digital marketing training program should design the training materials, determine the methods and techniques in which learning takes place. It can be compiled from the whole of series of activities starting from the beginning to the end based on this arrangement, the order in which this program is organized is stated below:

a) Participants recruitment

b) Learning resources

c) Time

d) Facilities

e) Training activities

f) Training resources

- Training for trainers. The implementation process of training can be understood based on the series of programs, scope of learning, training materials, and methods used. This is because facilitators or trainers are also required to understand the characteristics of the participants and their needs, hence the need of training for trainers to ensure that participants' need are met.

- Then, to carry out an evaluation of the participants to see the participants' progress after participating in the training program by conducting a pre-test which can be done either orally or in writing.

- Next is the training implementation. The implementation of the training program requires an interactive educational process between trainers and training participants in order to achieve predetermined goals. During this process, various kinds of dynamics can occur that will lead training program effectively as well. All abilities and components certainly need to be put together so that the training process can produce maximum results.

- Next, is the final evaluation. This stage it is carried out in order to measure the success of learning. From the existence of this program of activities, it is expected that the acceptance and absorption of the community or citizens can be seen from the material provided by the trainers and organizers. Therefore, the organizers are required to determine a follow-up activity immediately.

- In conducting the evaluation of the digital marketing training program, it is an activity for the assessment of all training activities from the initial stage to the final stage. The results afterwards become a reliable input for further training development. In addition, it is expected for evaluations to help trainers maintain the good factors, and identify weakness points as well. In this activity, of course, what is assessed is not only the results, but also the process that has been carried out from the beginning to end. Therefore, a comprehensive and objective picture of the activities that have been carried out by the participants during the training program can be obtained.

\section{B. Program Planning for the Implementation of Digital Marketing Training}

The implementation is always preceded by a needs analysis, then a digital marketing training design is created and followed by the development of digital marketing training materials before conducting training and ending the program with an evaluation. This kind of implementation can be said to be the standards for any training provision. The difference between one training and another lies in the learning approach and training organization. However, they still share the same goal, that is to increase the knowledge, skills and attitude of the training participants. From the results of an interview conducted with informants A and B as training organizers and instructors, activities like this are very helpful in the process of business continuity for small business players, meanwhile informant $\mathrm{C}$ as a training participant also revealed that digital marketing training for small business players are very important and useful for him, especially during the Covid 19 pandemic, which is very helpful to increase sales through a more effective marketing strategy for his business. According to informant $\mathrm{C}$, the manager is responsible to carry out these stages in digital marketing-based training for small business players to increase entrepreneurial motivation from the expression that has been explained according to Davies [12] that as a process, management is a training program that conveys three main activities of the program: (a) planning training programs, (b) implementing training programs, and (c) evaluating training programs. Furthermore, there are 3 components that can be further developed into activities depending on the approach used. The hierarchical management training procedures include: first, performing the initial stage of identifying and analysing the needs of the training program, second, testing and analysing given tasks, third, classifying and 
determining training participants, fourth, designing clear and concrete training objectives, fifth, designing training curriculum and syllabus, sixth, planning activities for the training programs, seventh, preparing and developing Terms of Reference (TOR), eighth, implementing training programs, ninth, evaluating training programs, and finally, managing follow-up trainings.

Based on the initial steps, to manage a training program is a description and analysis based on training needs from its institutional nature and the unit within the institution which of course has a distinct character. Training can be classified into two different types: the current needs or the needs of the training program in the future, as a result of changes. On the other hand, these steps are also conducted through identifying resources for problems to be resolved immediately by taking steps according to the priority scale, by being able to test any part or unit and position to determine the priority scale, as well as testing based on what position needs to be prioritized by analysing tasks or analysing positions through task analysis, job descriptions and job specifications as a result of changes.

\section{Digital Marketing Training Program Implementation}

The implementation carried out by the organizer aims to provide support throughout the program despite any issues that may arise such as funding constraints or limited resources which can be tackled by using a priority scale conducted through identifying resources for problems to be resolved immediately by taking steps according to the priority scale, by being able to test any part or unit and position to determine the priority scale, as well as testing based on what position needs to be prioritized by analysing tasks or analysing positions through task analysis, job descriptions and job specifications, then proceed to analyse knowledge and skills which of course require the fulfilment of the expected "standards" of an existing task. In connection with the results of the analysis, as for the next step, the "who" or the "potential participant" can be determined for participating in the training program. Furthermore, a more detailed and specific steps can be compiled from the stages in program planning by designing a curriculum and planning a training program beforehand in a participative manner, involving various parties to carry out the training program, to form a better commitment in order to create a supportive atmosphere during the implementation process, as well as after the training. In general, the planning process may take up more time than the implementation process, due to things that need to be considered including: 1) determining research background, 2) determining training objectives , 3) recruiting training participants, 4) determining the cost and source of funds, 5) determining the time and place of training, 6) designing a research schedule (time, materials and speakers), 7) arranging an implementation committee, 8) making arrangements orderly and, 9) determining sources for program implementation.

From the existence of an implementation process, no training programs can be completed within a short amount of time as it requires intensity, frequency, and a set duration of training, which should be sustainable, demanding elements that must be well managed. The approach to a training management system is supposed to be systematic and results-oriented. Each of the components should be linked with each other, hence the best results can be achieved. According to Djudju Sudjana, a successful learning can be influenced by the existence of 3 conditions of education, namely consistency, convergence, and continuity. Based on these results, consistency is related to a sequence of activities in education that must be appropriate and harmonious in the purpose of developing the existing potential in students. The convergence provides a deeper meaning related to education which can be contradicted by a clear and pre-designed foundation. The continuity is related to the belief that education must be sustainable [13].

\section{Digital Marketing Training Program Evaluation}

During the implementation process, there are several important points that need to be considered: the implementation of the training which requires a decent communication, logistics, facilitators, participants and other supporting infrastructure which are known as the program materials. Furthermore, in relation to the implementation of this evaluation, there are many other training programs carried out without any program evaluations. Program evaluations is helpful to illustrate the big picture of the implementation process, hence, a training evaluation requires a follow-up activity as well in order to provide the overview for the organizer to make a thorough evaluation of the training program. Things that can be observed during program evaluations are the ability of the participants before and after the program, creativity, attitude, skills, and interests.

In relation to the relationship bonding between the trainer and the participants, the relationship is said to supposedly be interactive, proactive, and reactive. Through an interactive relationship, it will encourage a good and harmonious cooperation. A proactive relationship can help trainers to be more initiative, while a reactive relationship will encourage participants to be more responsive. Based on the successful output indicators of the training determined by the components including the trainer, training participants, materials, strategies, media and training conditions. Therefore, training must incorporate both honest and trustworthy characteristics, a commitment in speaking words and performing actions, fair and egalitarian, with a humble nature, in order to create nuances of intimacy, patience, selflessness, and wisdom in becoming better during the implementation of the training program.

To implement training, various strategies can be used, such as: (1) preparing the participants for training, (2) using audiovisual media, (3) doing practical tasks, (4) preparing proportional materials, (5) communicating through dialogues and rationalization, (6) telling stories, ( 7) using visual images, sketches and drawings, (8) utilizing enthusiasm, (9) showing gestures (kinesics), (10) providing arguments, (11) monitoring creativity, (12) practicing repetition, (13) mapping, ( 14) encouraging participants to be creative, (15) giving answers to 
participants, (16) explain the answers of students, and (17) using a fair method in answering questions given by participants with patience.

Management of a training program is a process of character building in order to achieve the goal to help participants improve their skills. From one of the processes, management in the training program coincides within these 3 activities in program management: (a) planning, (b) implementation, and (c) evaluation. From these three components, it can be concluded into the term, "systematic training approach". Managing a training program is no different from managing other projects that we are familiar with. In determining indicators of a successful training, we can observe various aspects including trainers, training participants, training materials, learning facilities, learning strategies, training conditions. In addition, the presence of a good coach is a major determinant of success.

\section{CONCLUSION}

The management system of digital marketing training to increase entrepreneurial motivation for small business players in Cimahi is divided into 3 stages. The first stage is the planning stage of the training program, the second stage is the implementation of the training program, and the third stage is the evaluation of the training program. In its implementation, there are several things that need to be taken into consideration by the training organizers regarding communication, logistics, facilitators, participants and other supporting infrastructures. Lastly, training evaluations and follow-up activities are also crucial to indicate how well the materials are received by the participants. Training evaluations and follow-up activities are also very important to find out both weaknesses and strengths of the whole implementation process.

\section{ACKNOWLEDGMENTS}

We would like to express our greatest gratitude to the Institute of Research and Community Service, Universitas Pendidikan Indonesia for funding this research.

\section{REFERENCES}

[1] S. Soewardi, Pengukuran dan Hasil Evaluasi Belajar. Sinar Baru, 1987.

[2] S. Margono, Pertumbuhan dan Peranan Lembaga Swadaya Masyarakat dalam Pembangunan. CV Ramadhani, 1995.

[3] A. Abbas, A. Litchman and S. Pillai, Celluler and Molecular Immunology. Saunders Elsevier, 6th Ed, 2015.

[4] B. Saragih, Suara Dari Bogor: Membangun Opini Sistem Agribisnis. IPB Press, 2010.

[5] E. Ekawakib, S. Syam'un, S. Simon and M. Matkene, Efisiensi FaktorFaktor Produksi dan Kemitraan Guna Meningkatkan Usahatani Kedelai di Distrik Makimi Kabupaten Nabire Provinsi Papua. Papua, 2011.

[6] R. Sanjaya and J. Tarigan, Creative Digital Marketing. Jakarta: PT Elex Media Komputindo, 2009

[7] M. Hebies, Prospek Usaha Kecil dalam Wadah Inkubator Bisnis. Ghalia Indonesia, 2009.

[8] M. McClelland, Pengantar Kewiraswastaan. Intermedia, 1995.

[9] L.J. Moleong, Metodologi Penelitian Kualitatif. PT Remaja Rosdakarya, 2007.

[10] D. Sudjana, Pendidikan Luar Sekolah. Falah Production, 2001.

[11] M. Kamil, Model-Model Pelatihan, 2003.

[12] D. Davies, Objective In Design Curriculum England. Maiden Head, 1976.

[13] S. Sudjana, Penilaian Hasil Proses Belajar Mengajar. PT Remaja Rosdakarya, 1983. 